cance. The inheritance of a common mutant dominant gene from one or other great grandparent is the most cogent explanation. However, the gene is not expressed in any relatives in the two intervening generations. This raises the possibility, discussed by David $^{6}$ in relation to ectrodactyly, of a single mutant autosomal dominant gene under epistatic control of a gene, or genes, elsewhere in the genome. When the mutant gene is inherited without the 'protective' gene or genes, deformity will occur. That more than one 'protective' gene may be involved is suggested by the reports of acheiria and mid forearm amputation occurring within the same family. ${ }^{13-5}$ Forearm amputation is, like acheiria, a rare defect $(1: 25000)$ and would be unlikely to be associated, by chance alone, with acheiria in the same family. The extent to which the mutant gene is expressed could be dependent on the number of 'protective' genes also inherited.

Another possible issue to consider is germinal mosaicism, but the reports of acheiria and mid forearm amputation in the same family do not favour the presence of a single mosaic mutant gene.

Delayed gene mutation could be a theoretical explanation in the family reported here, but the family in which a great grandmother had acheiria and her great granddaughter a mid forearm amputation $^{5}$ would be rather against such a factor operating. The suggestion that the sex of the parent may be relevant to gene expression in the offspring, owing to differential 'genome imprinting' during oogenesis and spermatogenesis, ${ }^{78}$ is not of rele- vance in this context. Inheritance in case 1 was male-female-male and in case 2 female-femalefemale; neither is there any sex differential in any $\overline{0}$ other reported familial cases of acheiria or acheiria and mid forearm amputation.

From the relatively few case reports where acheiria has recurred within a family, or has been associated with mid forearm amputation, we would favour the presence of a mutant gene, in the absence of a 'protective' gene or genes to account for the deformity.

\section{References}

${ }^{1}$ Birch-Jensen A Congenital deformities of the upper extremities. O Copenhagen: Munksgaard, 1949.

2 Hecht JT, Scott CL Jr. Recurrent unilateral hand malformation in siblings. Clin Genet 1981;20:225-8.

3 Pilarski RT, Pauli RM, Eligber WD. Hand-reduction malfor- 0 mations: genetic and syndromic analysis. $J$ Pediatr 1985;5: 274-80.

${ }^{4}$ Kohler HG. Congenital transverse defects of limbs and digits. Arch Dis Child 1962;37:263-76.

5 Etches PC, Stewart AR, Ives EJ. Familial congenital amputa- $\frac{\widehat{\bigcirc}}{\supset}$ tions. J Pediatr 1982;101:448-9.

6 David TJ. Dominant ectrodactyly and possible germinal mosaicism. J Med Genet 1972;9:318-20.

7 Cattanach BM, Kirk M. Differential activity of maternally and paternally derived chromosome regions in mice. Nature 1985; 315:496-8.

${ }^{8}$ Sapienza C, Peterson AC, Rossant J, Balling R. Degree of methylation of transgenes is dependent on gamete of origin. Nature 1987;328:251-4.

Correspondence to Dr M Lamont, Department of $\underset{\vec{B}}{\overrightarrow{7}}$ Child Health, Southampton General Hospital, ㅇํำ Southampton SO9 4XY.

\title{
Identification and characterisation of a small marker chromosome using non-isotopic in situ hybridisation with $\mathrm{X}$ and $\mathrm{Y}$ specific probes
}

\author{
JOHN A CROLLA*, MARY SMITH, AND ZOE DOCHERTY \\ From the Paediatric Research Unit, Division of Medical and Molecular Genetics, United Medical and Dental \\ Schools of Guy's and St Thomas's Hospitals, Guy's Hospital, London SE1 9RT.
}

SUMMARY A 13 year old male with mild mental retardation, obesity, and poor secondary sexual differentiation was found to have a 46,X, + mar karyotype. In situ hybridisation with $\mathrm{X}$ and $\mathrm{Y}$ specific probes proved the marker to be composed of $Y$ centromeric and short arm material.

\footnotetext{
*Present address: MRC Experimental Embryology and Teratology Unit, MRC Laboratories, Woodmansterne Road, Carshalton, Surrey SM5 4EF.

Received for publication 10 June 1988 . Accepted for publication 28 June 1988.
}

\section{Case report}

The proband, a 13 year old mentally retarded male, was referred because of poor secondary sexual development and gynaecomastia. He was thought to $\stackrel{\odot}{\odot}$ be a possible case of Prader-Willi syndrome. He was $\stackrel{\overbrace{}}{\rightarrow}$ born at 37 weeks' gestation weighing $1956 \mathrm{~g}$ to healthy and unrelated parents. Two sibs, one $\overrightarrow{0}$ younger and one older, are both healthy and $\mathbb{\mathbb { D }}$ normal. At two years, the patient's right testis was $\overrightarrow{\mathbb{D}}$ brought down surgically and the other descended $\frac{\varrho}{\circ}$ spontaneously at seven years. His development has 

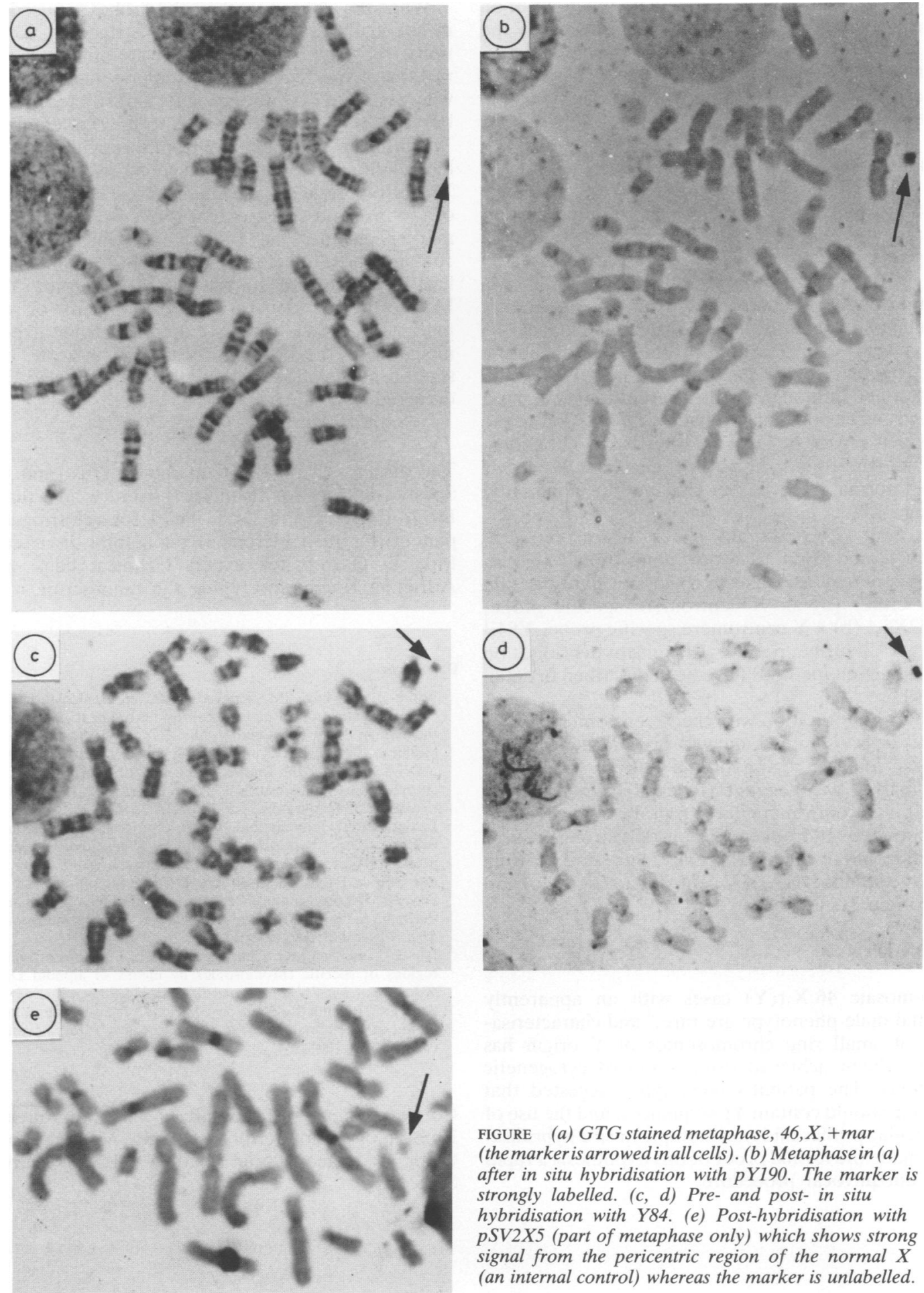

FIGURE (a) GTG stained metaphase, 46,X, + mar (the marker is arrowed in all cells). (b) Metaphase in (a) after in situ hybridisation with pY190. The marker is strongly labelled. $(c, d)$ Pre- and post- in situ hybridisation with Y84. (e) Post-hybridisation with pSV2X5 (part of metaphase only) which shows strong signal from the pericentric region of the normal $X$ (an internal control) whereas the marker is unlabelled. 
always been slow and at 13 years he functions at an eight to nine year old level. His height is below the 3 rd centile. Obesity is a continuous problem and on examination he was found to have a small penis and testes for his age and to show no evidence of the onset of puberty.

\section{Conventional and in situ cytogenetic studies}

Standard and FUdR treated high resolution metaphase spreads were prepared from PHA stimulated lymphocytes. Karyotype analysis of 34 GTG stained and 30 in situ metaphases showed that all cells contained 46 chromosomes with 22 apparently normal pairs of autosomes, a structurally normal X, and a very small marker chromosome, possibly a ring (figure $a, c) . Q$ banding was negative on the marker and, although the high resolution metaphase spreads were poor, no evidence of a deletion in the proximal region of $15 q$ could be found. C banding was not carried out. The karyotypes of both parents were normal, the father having an apparently normal $Y$.

Several GTG stained slides were prephotographed and then used for non-isotopic (biotin/ immunoperoxidase detection) in situ hybridisation with either (a) an $X$ centromere specific probe, $\mathrm{pSV} 2 \mathrm{X} 5,{ }^{1}$ (b) a Y centromere specific probe, Y84, ${ }^{1}$ or (c) a Yp probe, $\mathrm{pY} 190 .^{2}$ The in situ hybridisation and detection methods have been described in detail elsewhere. ${ }^{3}$

After hybridisation with the $\mathrm{X}$ centromere probe, all 10 cells examined showed one signal from the pericentromeric region of the normal $X$ and the ring/marker was negative (figure e). When probed with the $\mathrm{Y}$ centromere and Yp probes, however, all cells studied (10 from each) showed a strong positive signal from the ring/marker only, therefore showing that it contains DNA of $Y$ centromere (figure d) and Yp origin (figure b).

\section{Discussion}

Non-mosaic $46, X, r(Y)$ cases with an apparently normal male phenotype are rare ${ }^{4}$ and characterisation of small ring chromosomes of $\mathrm{Y}$ origin has usually been achieved using standard cytogenetic methods. The patient's phenotype suggested that the ring should contain Yp sequences, and the use of molecular probes and non-isotopic in situ hybridisation made the formal proof of this hypothesis a rapid and unequivocal procedure.
When the alphoid centromeric probes are used for in situ hybridisation under high stringency condi- $\overrightarrow{\vec{S}}$ tions, they hybridise specifically to the A-T rich $\overline{0}$ regions of the $\mathrm{X}$ and $\mathrm{Y}$ centromeres respectively, ${ }^{5}$ 듬 whereas the pY190 probe signal is restricted to Yp, $\frac{\bar{s}}{\sigma}$ but does not appear to extend to the Yp telomere. $\frac{\Phi}{\circ}$ The in situ results obtained from these three probes have defined the marker to be comprised largely of ${ }^{\infty}$ $\mathrm{Y}$ centromere and a portion of Yp. The phenotype. of the proband suggests that the Yp portion of the $\overrightarrow{\vec{\omega}}$ marker includes the $140 \mathrm{~kb}$ interval $1 \mathrm{~A} 2$ which $\stackrel{\omega}{\sigma}$ contains the $T D F$ (testis determining factor) which has been mapped to the distal region of Yp. ${ }^{6}$ Monitoring of the sexual development of this $N$ patient, together with Southern blotting experiments with the $T D F$ probes, may indicate if a $\overrightarrow{0}$ significant deletion within the $T D F$ region has $N$ occurred.

The authors thank the Generation Trust and the Spastics Society for financial assistance. We thank $\vec{\theta}$ Dr A C Berry and Dr C Pearl for referring the patient; Dr Juan Llerena Jr for helpful discussion; Miss D Garrett for expert technical help; and Adrienne Knight for typing the manuscript.

\section{References}

1 Wolfe J, Darling SM, Erickson RP, et al. Isolation and characterization of an alphoid centromeric repeat family from the human Y chromosome. J Mol Biol 1985;182:477-85.

2 Müller U, Donlon TA, Kunkel SM, Lalande M, Latt SA. Y-190, a DNA probe for the sensitive detection of Y-derived marker chromosomes and mosaicism. Hum Genet 1987;75:109-13.

${ }^{3}$ Crolla JA, Gilgenkrantz S, de Grouchy J, Kajii T, Bobrow M. Incontinentia pigmenti and $\mathrm{X}$-autosome translocations: nonisotopic in situ hybridization with an X-centromere specific probe (pSV2X5) reveals a possible centromeric breakpoint in one of five published cases. Hum Genet (in press).

4 Davis RM. Localisation of male determining factors in man: a thorough review of structural anomalies of the Y chromosome. $J$ 윽 Med Genet 1981;18:161-95.

5 Jabs EW, Persico MG. Characterisation of human centromeric $\frac{7}{O}$ regions of specific chromosomes by means of alphoid DNA sequences. Am J Hum Genet 1987;41:374-90.

6 Page DC, Mosher R, Simpson EM, et al. The sex determining region of the human $\mathrm{Y}$ chromosome encodes a finger protein. $\mathrm{N}$ Cell 1987;51:1091-104.

Correspondence to J A Crolla, MRC Experimental $\stackrel{\circ}{\varnothing}$ Embryology and Teratology Unit, MRC Labora- $\stackrel{\mathcal{D}}{\rightarrow}$ tories, Woodmansterne Road, Carshalton, Surrey SM5 4EF. 